Original scientific paper

\title{
REGIONAL DEVELOPMENT TRENDS AND THE REGIONAL DEVELOPMENT INSTITUTIONS IN THE VISEGRAD COUNTRIES - ENABLING OR HINDERING INSTITUTIONAL ENVIRONMENT?
}

\author{
György NAGYHÁZI ${ }^{\text {a }}$ \\ ${ }^{a}$ Szent Istvan University, Faculty of Economic and Social Sciences, Address: 17, Budai Nagy Antal Street \\ 2890, Tata, Hungary. Phone: +36-30/2350648, e-mail: nagyhazigy@gmail.com; \\ gyorgy.nagyhazi@nfm.gov.hu
}

Cite this article: Nagyházi, G.. (2015). Regional Development Trends and the Regional Development Institutions in the Visegrad Countries - Enabling or Hindering Institutional Environment?. Deturope, 7, 2: $28-44$

\begin{abstract}
Different regional development patterns and processes have emerged in the Visegrad countries (Czech Republic, Hungary, Poland and Slovakia) since their accession into the European Union, in the past ten years. The reasons behind these different regional development trajectories mostly have been contributed quite rightly to the economic transformation processes where these post-socialist countries have to reorganize and to reconstruct their economies.

The aim of this paper is to highlight the possible linkages between the individual countries' particular central and territorial development institutional settings with the different regional development process trajectories: the two types of regional development systems in the Visegrad countries (centralized and decentralized) and the two main regional development processes (growing and non-growing regional disparities).
\end{abstract}

Keywords: Regional Development, Institutions, Regional Disparities, Subsidiarity

\section{INTRODUCTION}

In the Visegrad countries there is one general phenomenon: the emerging development disparities between the capital regions and between the rest of the countries' regions, as it is highlighted in the Cohesion Reports of the European Commission. However, apart from this general feature, there are different trends in these countries' regional economic developments.

In the pre-accession process of these countries, the subject of multi-level governance had played an important role in negotiating with the European Commission (Bache, 2010). The incentive coming from the commission was twofold in the process of the adoption of the "Regional policy and coordination of structural instruments" chapter of the common European law. On the one hand the commission had effectively been pushing the countries towards a devolved, decentralized governance structure and on the other there was the objective to create an effective administration system, which can manage the European development 
funds. The result has been emerging various territorial self-government and regional development systems in the new member states (Bruszt, 2007 and 2008, Scherpereel, 2007). $55 \%$ of the regulatory frameworks have been prescribed by the EU institutions, and the new member states have been responsible for the remaining 45\% (Wostner, 2008).

\section{THE ROLE OF INSTITUTIONS IN REGIONAL DEVELOPMENT}

The national level - which had traditionally been considered to be the main focus of economic policy - has gradually lost of its importance mainly as the result of the various international treaties and emerging free trade systems especially within the European Union. In economic development policy literature a shift of attention has taken place where the source of competitiveness is increasingly considered to be the regional/local micro-economic level. Specific attention has been given to the territorial aspect of various factors and endowments which are more and more considered to be the localized source of economic development in the globalized world, making up the concept of territorial capital (Camagni, 2009). These local and regional factors can also be seen as "institutions". According to the institutionalist view (Amin, 1999), the key element in the economic development of the regions is the "ability to evolve in order to adapt" (Amin, 1999, 372). The role of governance is especially important in the case of the less favored regions in mobilizing and building up local resources and capacities (Amin, 1999, 375).

Institutions (formal and informal) can be found in various forms in times and in places, consequently there are considerable difficulties to formulate adequate economic development policies which are primarily focusing on them. On the level of a national government, it is especially demanding to define the most appropriate economic development policies for any given region. There is the view, that regional development policy can only be effective when it is executed on regional level, with an institutional focus (Rodrigues-Pose, 2010). As Elinor Ostrom (Ostrom, 2007) has established - based upon the analysis of the various governance systems of collective goods -, that on any fields of social interactions the self-governing systems are more efficient. The source of this superior efficiency is not coming from the magical "grass-roots" quality, but rather it's a reflection of the fact that the social capital in these systems - which is created by the operational (formal and informal) rules - is more likely to survive and to develop in the networks and norms created by the participants. This can also be seen as the real basis of the recently emerged concept of economic resilience and resilient regions (Tóth, 2012). There is also the view, that "market preserving federalism" (Weingast, 1995), that is "the political decentralization of economic authority" (Weingast, 
$1995,6)$ have been historically the key factor in economic growth and development in various countries. These considerations give a more general framework for analysis of the Visegrad countries' regional development institutions, then the so called "effectiveness view", where usually the institutional arrangements considered only from the point of view of the "absorption of the EU funds" (Perger, 2009). Regional economic development, on the contrary is usually been analyzed and explained from multitudes of aspects, but "unfortunately, the economists' focus ignores politics" (Weingast, 1995, 2) and the role of formal and informal institutions (North, 1994). Based on these considerations, the regional development institutions of the four countries can be analyzed in a wider framework. It is especially important to see, to which extent these institutional developments were part of a larger scale institution building and especially effective decentralization processes in the Visegrad countries.

\section{REGIONAL DEVELOPMENT INSTITUTION SYSTEMS IN THE VISEGRAD COUNTRIES - CENTRAL INSTITUTIONS}

In Poland, the Ministry of Regional Development has been established right after accession of the country into the European Union in 2005 and was operating until 2013 with the same portfolio. From then on, the Ministry has taken over the responsibility for transport, building and maritime affairs, too.

In the Czech Republic, the Ministry of Regional Development has been established in 1996, and operating then on with the same portfolio. The responsibilities of the ministrybesides regional development - are including the housing and construction affairs, public procurement, spatial planning, investment policy and tourism.

In Slovakia, the Ministry of Regional Development and Construction has been operating since 1999. The ministry in the meantime had been merged with the Ministry of Transport and Communications. In addition to the regional development portfolio, the ministry is also in charge for construction, tourism, telecommunication and PPP (Public Private Partnership) projects as well.

In the case of Hungary there is an ever changing government structure concerning regional development. Compared to the other Visegrad countries in Hungary, the responsibility for the management of regional development policies has very frequently been restructured in the central government (Rechnitzer, and Smahó, 2011). It has been the subject of intra governmental reorganization for five times since 2004. In Hungary there had been a separate national office in charge for the management of the European funds (including the European 
Regional Development Fund), and there is a separate central administration for regional development, which was managing domestic funds. It was an unusual solution, since in Hungary the central management of regional development in the middle of the 1990's, was established in order to be prepared for the EU accession. The resulting situation has been regarded as "the house built next to its foundations" (Pálné Kovács, 2004; Perger, 2010). One can observe an unusual institutional instability on the level of the central government in this policy area.

Thus concerning central government institutions dealing with regional development the situation was rather stabile in the other Visegrad countries compared to Hungary. This stability is all the more striking given the fact that in Poland, in the Czech Republic and in Slovakia too, the ministries of regional development are also responsible for the management of EU funds and cohesion policy at the same time. There are even more remarkable contrasts between the other three countries and between Hungary in the territorial institutions of regional development.

\section{THE TERRITORIAL SYSTEM OF REGIONAL DEVELOPMENT IN POLAND AND THE ECONOMIC DEVELOPMENT PROCESSES OF THE REGIONS}

In Poland the regional self-governments, the voivodships are responsible for regional development. The 1999 administration and local government reform (OECD 2008) has created three layers of territorial division of the country. The 16 voivodships are at the NUTS II, regional level. The voivodship self-governments - among other things - are responsible for the regional development planning and for the implementation of plans, and all of them are having their own regional development agencies. In Poland - as it was noted earlier - the formation of territorial self-governments and the creation of the regional development system went hand in hand in a coherent manner. The subsidiarity principle in the decentralization process has been closely observed (Kulesza, 2002; Mezei and Schmidt, 2013). The creation of the Polish system of self-governments had been a long procedure which had already been started in 1989, and it had been ongoing for ten years, until 1999. The key momentum was the adoption of the new constitution in 1997, in which the subsidiarity principle and the foundations for the self-government system's fiscal autonomy have been laid. The voivodships have been established in a planned and organized way, based on a political and social consensus. The decentralization processes in Poland have resulted real autonomy for the local and territorial self-governments, in which fiscal autonomy was a key factor.

\section{4-2006 programming period}


Right after the EU accession one regional development plan was implemented for all the regions in the country financed from EU funds. This single regional operational program had been managed and implemented in cooperation with the voivodships and the Ministry for Regional Development. These experiences have been considered by all the participants as a learning process by the help of which the voivodships were preparing for independent program planning and implementation (Dabrowski, 2007). The Voivode (the representative of the government) and the Marshall (elected head of the assembly) had a split responsibility in the execution of the program, while the partnership principle has been applied through the establishment of the regional management committees. The regional development agencies have also been established in this period.

\section{7-2013 programming period}

In the current recently closing programming period of 2007-2013, all the voivodships have implemented their own regional operative programs. In this period $25 \%$ of all the EU funds have been allocated and spent in the framework of regional programs. Looking at the effectiveness of Polish regional policy, the regional disparities have been grown between 1995 and 2009, where the capital region and the western regions developed more rapidly. The recent development processes of the Polish voivodships show (Fig. 1), that apart from still significant difference between the capital region (Mazovia) and the rest of the regions, the development disparities have not grown dramatically within Poland. 
Figure 1 Change in GDP / capita in the Polish Regions Between 2000 and 2011, in USD constant PPP, constant (real) prices (year 2005)

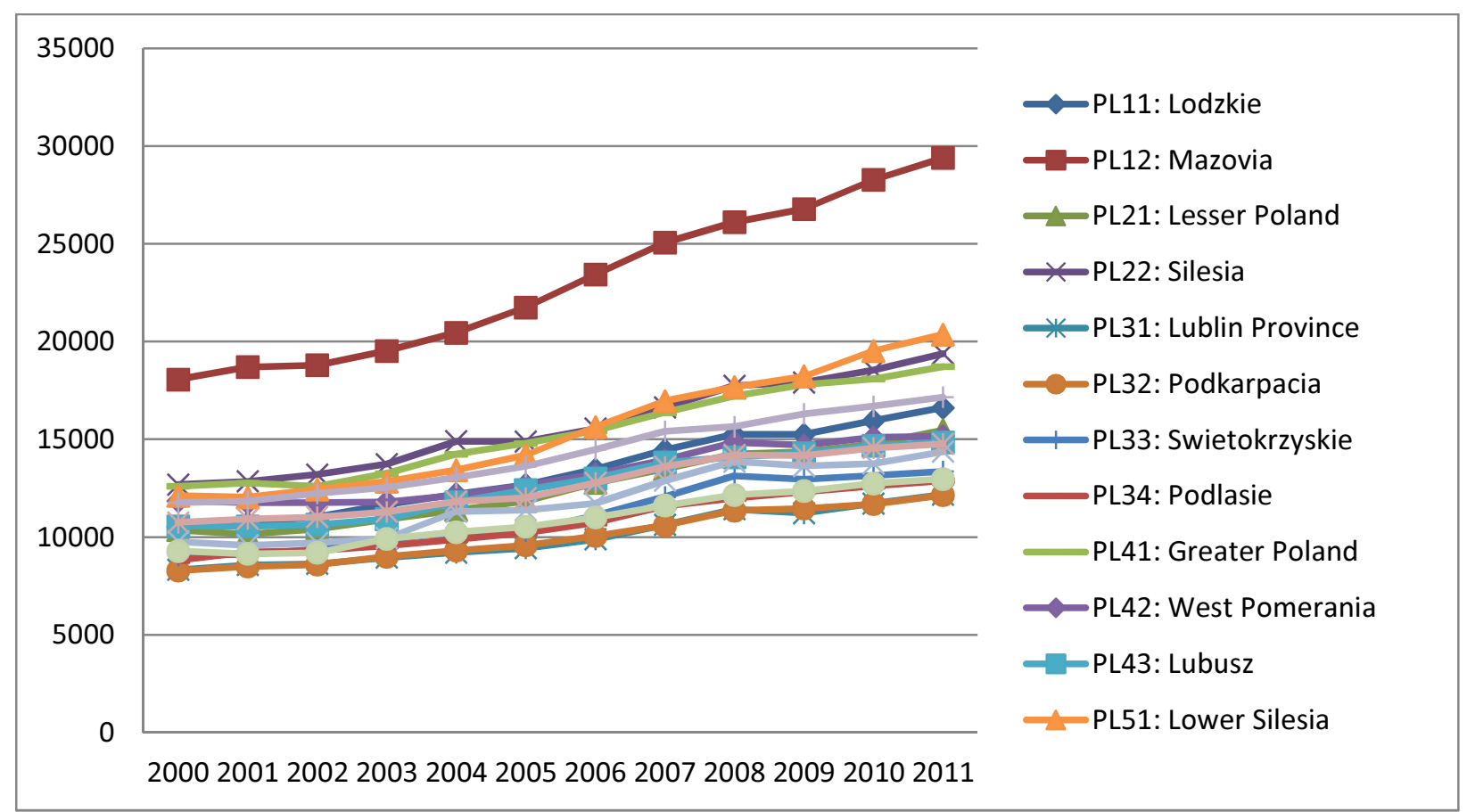

Data source: OECD (OECD 2014)

In the Polish case it can be observed that the 2008-2010 world economic crisis have not made a significant impact upon the development of the regions. The main issue here is that even the less developed regions are going ahead, and - according to the EuroStat (EuroStat, 2014) only one region is below the $50 \%$ development threshold (only with $1 \%$ ).

\section{THE TERRITORIAL SYSTEM OF REGIONAL DEVELOPMENT IN THE CZECH REPUBLIC AND THE DEVELOPMENT PROCESSES OF THE REGIONS}

In the Czech Republic, like in Poland, the territorial self-governments are responsible for regional development. Here also a lengthy debate had taken place, which preceded the establishment of the regional government system (Baun, and Marek, 2006; McMaster, 2004; Neuman, and Neuman, 2010). The EU accession had played a significant role in the making of a decentralization process (Brusis, 2003). The European Commission had exerted pressure on the country in order to establish a territorial self-government system. Right after the "velvet revolution", local governments have been established. On district level governmental offices operated above the level of the more than 6.000 local governments. These offices were belonged to the Ministry of Interior, and the other ministries operated branch offices in them (Suchacek, 2005). The large number of local governments had created coordination problems for the central government (Blazek, 2002), but this situation had initiated some spontaneous 
solutions, too like the Ostrava-Kravina agglomeration's social and economic council (Suchacek, 2005). In the Czech Republic the establishment of the territorial self-governments has been a result of the Act on Regional Governments, which came into force in the year of 2000. The newly established regional government bodies' competencies and the role of the regions had been consolidated until 2004 and their identity creation role had also been increased. Many uncertainties surrounded the financial system of the municipalities and the regions. The local and regional governmental finances have undergone major changes between 1990-1992, 1993-1995 and 1996-2000 (Blazek, 2002). The present system is operational since 2001. The Czech local and regional governments are enjoying real fiscal autonomy provided within a stabile legal framework since 2001. From among the established 14 regional governments only Prague, Moravia-Silesia and Central Bohemia meet the European NUTS II level criteria. Each region has a directly elected assembly. The competencies of the regional assemblies including regional development, the coordination between municipalities, secondary education, health, social care, public transport and the maintenance of the road network. The issue of the establishment of the Czech regions had been a subject of heated political debates, the result of which was a consensus about need and the usefulness of decentralization.

\section{4-2006 programming period}

In the Czech Republic there are eight NUTS II level cohesion regions. In addition to the already NUTS II level two regions, the other regions grouped to form NUTS II level cohesion regions. In this first period the Czech Republic has also implemented one singe Joint Regional Operative Program, in which the managing authority had been the Ministry for Regional Development, while there were the 26 intermediate bodies involved in the program's execution (Šumpíková, Pavel, Klazar, 2004). The Czech regional assemblies’ secretariats and the regional offices of the Centre of Regional Development were responsible for these tasks (Šumpíková, Pavel, and Klazar, 2004). Here this first period was conceived also as a learning process, and as the result of it, the regional self-governments had become ready for full-scale program implementation in the next period.

\section{7-2013 programming period}

In the Czech Republic all NUTS II level regions have had their own operational program in the currently ended 2007-13 cohesion period. The regions were responsible for the planning of the programs, and they have been responsible for implementation as well. The regional (2) and the cohesion regional councils (6) are the management authorities and their agencies are the intermediate bodies for their regional programs. It means that the Czech regions, similarly 
for the Polish voivodships are fully in charge for the management of their EU funds based development programs. The regional assemblies have also established their development committees in which the representatives of local governments, businesses, trade unions and non-governmental organizations involved. These committees are responsible for the monitoring activities.

Since their establishment, the Czech regional self-governments have played an important and growing role in regional development. Their approval has been increased and, according to some surveys, $85 \%$ of the Czechs are having regional identity (Baun and Marek, 2006).

The regional disparities in the Czech Republic are the second largest among the Visegrad countries after Slovakia, however this due to the outstanding development level of the capital city Prague. It should be noted that no Czech region is below the $50 \%$ of the EU average regional development level, even the most underdeveloped North-West region is standing at 63\% (EuroStat 2014).

The development trajectory of the Czech regions shows (Fig. 2.) - similarly to the case of the Polish regions - that there is no widening development gap among them.

Figure 2 Change in GDP / capita in the Czech Regions Between 2000 and 2011, in USD constant PPP, constant (real) prices (year 2005)

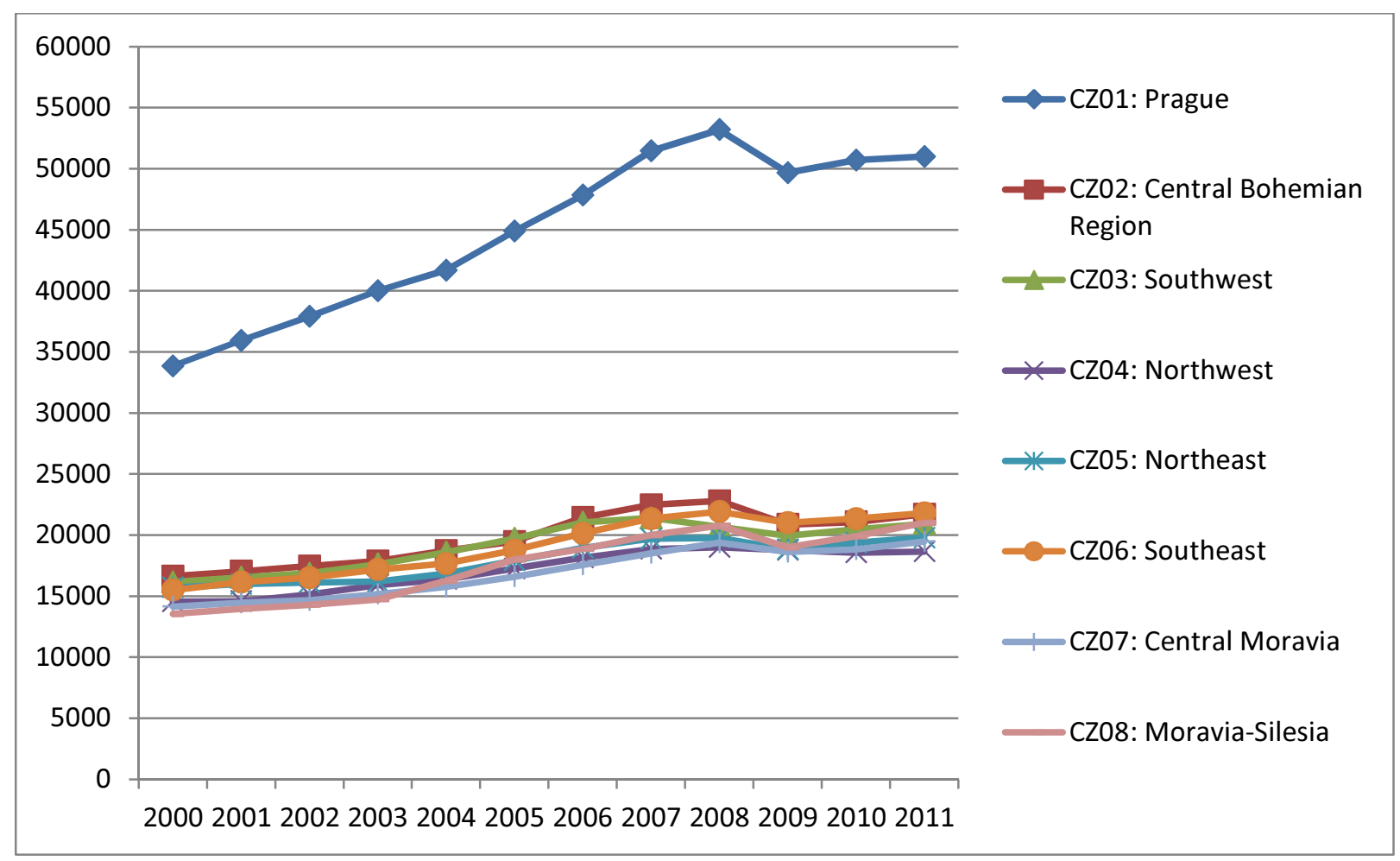

Data source: OECD (OECD 2014) 
One can observe in the above figure, that the 2008-2010 economic crisis has made an impact upon the Czech regions' development, but the gap between the most and the least developed NUTS II level region is very small - excluding Prague - and not widening. The territorial differences are the least significant compared to the other three Visegrad countries.

\section{THE TERRITORIAL SYSTEM OF REGIONAL DEVELOPMENT IN SLOVAKIA AND THE DEVELOPMENT PROCESSES OF THE REGIONS}

Slovakia's eight county governments were established in 2002. The counties' competencies are similar to the Czech regions', with the exception of health care, where they have fewer tasks. It should be noted however, that despite the fact that the counties' basic duties include the regional development task, they are only partially involved in the implementation of EU programs. In Slovakia the decentralization process has not been implemented fully: the counties do not enjoy the same level of competencies in regional development like their Polish and Czech territorial self-government counterparts (Brusis, 2003). The counties' fiscal autonomy is also limited; all their financial resources are coming from the central government.

\section{4-2006 programming period}

Slovakia had not implemented regional development operative program in the first cohesion period. The Agriculture and Rural Development Operative Program was the only territory focused, while the remaining four OPs were national level ones. (McMaster, Novotny, and Polverari 2005)

\section{7-2013 programming period}

Slovakia has been implementing a single regional operative program in 2007-2013. The managing authority for the regional programs is the Ministry for Agriculture and Rural Development, based on the ministry's previous experiences in territorial program management. The Slovak counties are operating only intermediary body organizations. Interestingly, the regional development agencies owned by the counties are only part of the 52 such organizations operating nationwide. These intermediary bodies are contracted directly by the Ministry for Regional Development, to provide support for the project beneficiaries in the implementation of their projects. Their responsibilities are regulated in the 2008. Act No. 539 on Support of Regional Development.

Slovakia territorial disparities are among the largest in the Visegrad countries. It is primarily due to outstanding development level of the capital (Michalek, and Podolák, 2011). In Slovakia even the least developed region is reaching 50\% of the EU average (Eurostat, 2014) 
in GDP/head terms. The average level of economic development of the Slovak regions is essentially similar to the Polish regions'. The experts of the OECD LEED program have recommended recently that the counties responsibilities in regional development should be increased (OECD LEED, 2012).

Figure 3 Change in GDP / capita in the Slovak Regions Between 2000 and 2011, in USD constant PPP, constant (real) prices (year 2005)

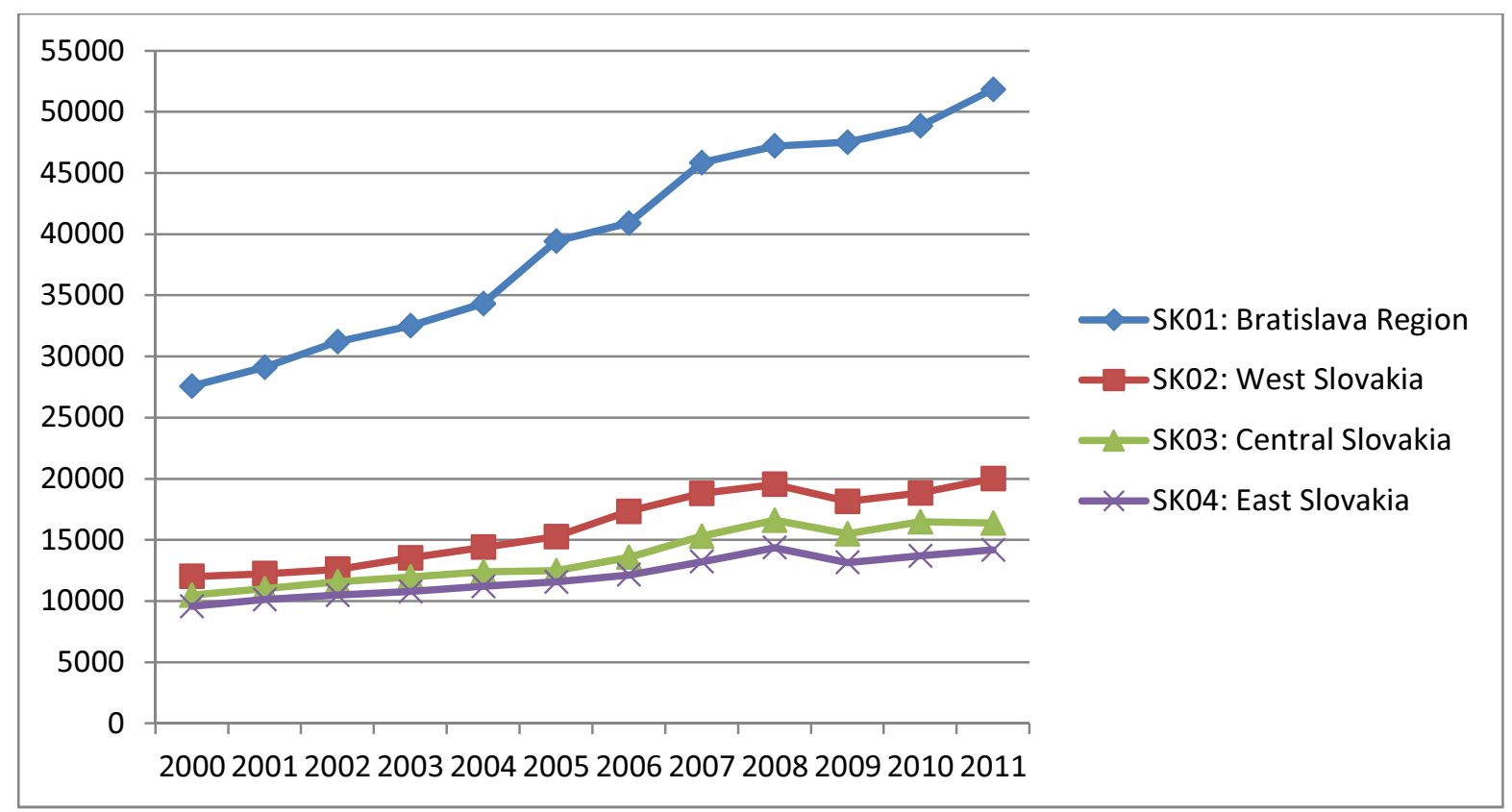

Data source: OECD (OECD 2014)

The (Fig 3.) three Slovak NUTS II level regions of West, Central and East Slovakia are showing diverging economic development dynamics - in contrast to the Czech and Polish experiences - where Eastern Slovakia falling back visibly.

\section{THE TERRITORIAL SYSTEM OF REGIONAL DEVELOPMENT IN HUNGARY AND THE DEVELOPMENT PROCESSES OF THE REGIONS}

In Hungary contrary to the systematic decentralization processes that have taken place in Poland, in the Czech Republic and to lesser extent Slovakia, an ever changing and complicated governance system for regional development has emerged, which has become more and more separated from the local governments.

With the establishment of local governments in 1990, the previous territorial development and coordination role of the counties had been abolished. At the same time the role and the importance of regional development planning had been downgraded. The counties (NUTS III level) while kept their role in providing territorial public services, had no taxation powers and 
relied entirely on transfers from the central budget without any fiscal autonomy. There were no incentives in place for the local governments for cooperation, and the small associations usually were alliances of the villages against center town of the area. In the perspective of the EU accession, county level development councils have been established in order to observe the partnership principle within which along with the representatives of the county local governments were participating the representatives of business and the NGO sectors. Later the regional development councils were organized on NUTS II level. A more general problem however, that the Hungarian local governmental sector can be described as "decentralization without subsidiarity" (Vígvári 2008), meaning that fiscal autonomy have been downgraded so seriously by the consecutive governments since 1990, that it totally undermined the local and the territorial governments" "decision making functions" (Capello, and Peruccia, 2013).

\section{4-2006 programming period}

Following the accession of Hungary into the EU, the first regional operative program had been a "unified" one, similar to the other Visegrad countries. The regional development councils (NUTS II) were included into the decision making process and their regional development agencies were participated into the planning and acted as intermediary bodies in the program. The competencies and the membership of the councils had changed six times between 1999 and 2012. The outcomes of the actual changes were almost always the scaling back of the competencies and more and more government appointee, "delegated" members.

\section{7-2013 programming period}

In the next cohesion period, the participation of the already operational regional development councils had been scaled back, which was an opposite development compared to the Czech Republic and Poland. The regional development agencies are again acted as intermediary bodies, but a central development agency had also started to open its regional offices and entrusted as intermediary body in the regional operative programs. While at the beginning of the period the regional development councils were managed some domestic funds, these had been scaled back significantly. The councils had a right to decide over 47 billion Ft domestic funds between 2007-2011, and they can only be consulted with about the 1252 billion Ft EU funds in "their" regional development program. After 2010, the entire development council system had been winded up, at January the $1^{\text {st, }} 2012$. The local governmental competencies and finances have been totally transformed. The county governments have lost all their public service provider responsibilities and competencies to the central government, while they have been entrusted with regional development as their only task. The fiscal autonomy of the counties have not improved, they are operating only from transfers from the central budget. 
The only players among the local governments with reasonable fiscal autonomy are the bigger towns, with appropriate business tax income, but they are "below of critical mass" (Lux 2013), meaning that they are insufficient in size to be a real regional economic growth pole. The regional development institutions (both formal and informal) have been subject to very frequent changes, in which the constant element was the systematic reduction of their "decision making functions".

The economic development level of the Hungarian regions show large differences, where four out of the seven regions are below the 50\% of the EU 27 average. The development gap between the most prosperous regions and the least ones have been growing, even more than in the case of Slovakia. The data shows no economic convergence in the cases of the four most underdeveloped Hungarian regions (Fig. 4.).

Figure 4 Change in GDP / head in the Hungarian Regions Between 2000 and 2011, in USD and in Purchasing Power Parity - PPP

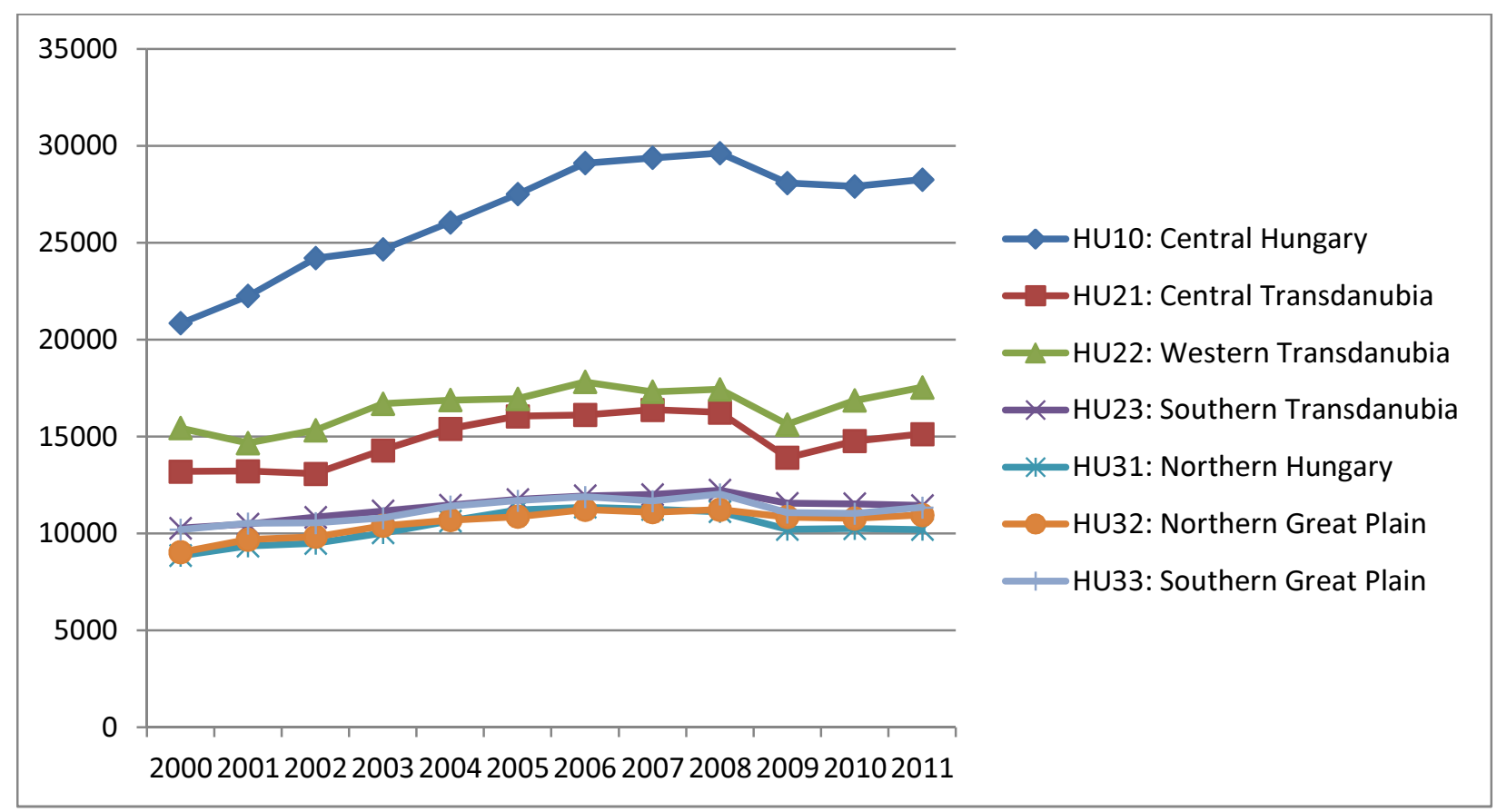

Data source: OECD (OECD 2014)

As it is clear from the above figure (Fig. 4.), the capital region (Central Hungary), Western and Central Transdanubia were able to regain their position following the 2008-2010 economic crisis, while the other four regions are lagging behind. Capello and Peruccia have analyzed the economic development of the Eastern European regions (Capello, Peruccia 2013). They have concluded that the successful Eastern regions are "relying more and more on local elements like knowledge..." (Capello, and Peruccia, 2013, 21.). Furthermore they 
claim that economic resilience is the quality of those regions, which were "able to increase the presence of decision making functions" (Capello, and Peruccia, 2013, 21.). This finding can be seen as a clearly reinforcing case for effective subsidiarity and decentralization.

In Hungary the regional development policies seem to be rather ineffective. As one of the chief scholars on public finances András Vígvári has put it "the regional development policies adopted since 1996, has not been able to slow down the growth of any regional disparities" (Vígvári, 2008, 164).

The reasons behind this relative ineffectiveness of the regional development public policy in Hungary are to be found largely in its institutional history, which is clearly in line with the conclusions of Capello and Peruccia. In Hungary the local and territorial self-governments and the regional development institutions, quite unprecedentedly have evolved into separate institutional systems. The regional development institutions went through extreme frequent changes concerning their competencies and territory.

The ever governing political forces have utilized the changes in development institutions, for their own short term political purposes by creating and serving rent seeking coalitions, while claiming that all the restructuring were necessary because of "European principles" (Pálné Kovács, 2013). Another study has claimed that "the party political influence, the weakened state (government) and the real lack of civic control had resulted the spreading of rent-seeking" (Pulay, and Vígvári, 2010, 229). Due to their centralized and frequently changing nature, the Hungarian regional development institutions have never been able to function as mechanisms of market preserving federalism (institutions of political decentralization of economic authority), and they - as it is seen from the above cited evaluations - were unable to diminish the level and the pervasiveness of economic rentsseeking and the formation of distributional coalitions (Weingast, 1995, 6). The road which has led to this situation was totally unplanned, and- despite all the recommendations - was not based on any kind of strategy or social and political consensus (Lóránd, 2009).

Comparing (Fig. 5) the 2007-2013 period regional development institutional settings in the four countries, it is visible that only the Czech and the Polish regions had real influence on their development policies, while their Slovak and the Hungarian counterparts had very minimal competencies. 
Figure 5 Regional development actors in territorial level in the Visegrad countries, and their main competencies

\begin{tabular}{|c|c|c|c|c|}
\hline & Hungary & Poland & Czech Republic & Slovakia \\
\hline $\begin{array}{l}\text { Territorial level } \\
\text { actors of regional } \\
\text { development } \\
2007-13\end{array}$ & $\begin{array}{l}\text { Regional } \\
\text { Development } \\
\text { Councils }\end{array}$ & Voivodships & $\begin{array}{l}\text { Regional } \\
\text { Councils }\end{array}$ & Counties \\
\hline $\begin{array}{l}\text { Their level of } \\
\text { fiscal autonomy }\end{array}$ & $\begin{array}{ll}\text { No fiscal } \\
\text { autonomy }\end{array}$ & $\begin{array}{l}\text { Medium level } \\
\text { fiscal autonomy }\end{array}$ & $\begin{array}{l}\text { Medium level } \\
\text { fiscal autonomy }\end{array}$ & $\begin{array}{l}\text { Low level } \\
\text { fiscal } \\
\text { autonomy }\end{array}$ \\
\hline $\begin{array}{ll}\text { NUTS II level } \\
\text { Operative } \\
\text { Programs }\end{array}$ & 7 Regional OPs & $\begin{array}{ll}16 & \text { Regional } \\
\text { OPs } & \end{array}$ & 7 Regional OPs & 1 Regional OP \\
\hline $\begin{array}{l}\text { Competencies in } \\
\text { the execution of } \\
\text { the regional OPs }\end{array}$ & $\begin{array}{l}\text { Owners of one } \\
\text { of } \\
\text { intermediate } \\
\text { body } \\
\text { organization in } \\
\text { their regions } \\
\text { until their } \\
\text { dissolution }\end{array}$ & $\begin{array}{l}\text { Full control and } \\
\text { ownership of the } \\
\text { managing } \\
\text { authority and } \\
\text { the intermediate } \\
\text { body } \\
\text { organization }\end{array}$ & $\begin{array}{l}\text { Full control and } \\
\text { ownership of the } \\
\text { managing } \\
\text { authority and the } \\
\text { intermediate body } \\
\text { organization }\end{array}$ & $\begin{array}{l}\text { Operating } \\
\text { intermediate } \\
\text { body } \\
\text { organization } \\
\text { (not exclusive } \\
\text { competency) }\end{array}$ \\
\hline $\begin{array}{l}\text { Decision making } \\
\text { competencies }\end{array}$ & $\begin{array}{l}\text { No decision } \\
\text { making } \\
\text { competency, } \\
\text { only opinions } \\
\text { can be } \\
\text { formulated }\end{array}$ & $\begin{array}{l}\text { Independent } \\
\text { decision making } \\
\text { competency }\end{array}$ & $\begin{array}{l}\text { Independent } \\
\text { decision making } \\
\text { competency }\end{array}$ & $\begin{array}{l}\text { No decision } \\
\text { making } \\
\text { competency, } \\
\text { only opinions } \\
\text { can be } \\
\text { formulated }\end{array}$ \\
\hline $\begin{array}{l}\text { Elected/Delegated } \\
\text { members }\end{array}$ & $\begin{array}{l}\text { Delegated } \\
\text { members are in } \\
\text { majority }\end{array}$ & $\begin{array}{l}\text { Only elected } \\
\text { members }\end{array}$ & $\begin{array}{ll}\text { Only elected } \\
\text { members }\end{array}$ & $\begin{array}{l}\text { Only elected } \\
\text { members }\end{array}$ \\
\hline
\end{tabular}

Edited by the author

\section{CONCLUSIONS}

In the Czech Republic and in Poland regional development policies have been integral part of the consensus based decentralization processes. In these countries the formal and the informal institutions have been consolidated (rules, practices, players), by the help of their competencies and autonomy. In these countries the regional disparities have not grown, the regional institutions have been able to mobilize endogenous resources and the regions are showing signs of economic resilience. Slovakia also showing diverging regional development pathways, but even the most underdeveloped Eastern Slovakia is above the 50\% EU average development level. Neither the central nor the territorial institutions have been able to consolidate their positions, and the subsidiarity principle was never seriously applied in 
Nagyházi, G.

Hungary. Regional development has become highly centralized and as a consequence, the most ineffective among the Visegrad countries. The "political decentralization of economic authority" (Weingast, 1995) had never been taken place here. No wonder that as a result of these processes the economic development pattern of the Hungarian regions are falling into the "ineffective reorganization" category (Capello and Perucca, 2013). Centralized regional development does not seem to be a working solution.

\section{REFERENCES}

Bache, I. (2010): Europeanization and multi-level governance: EU cohesion policy and preaccession aid in Southeast Europe, Southeast European and Black Sea Studies Vol. 10, No. 1, March 2010, 1-12

Báger, G., Pulay, Gy. \& Vígvári, A., (2010): A magyar államműködés főbb jellemzői és szükséges átalakítási irányai (The Main Characteristics of the Hungarian State's Operation and the Possible Directions for Restructuring). Pénzügyi Szemle, 2010/2., 217-242.

Baun, M., \& Marek, J. (2006): Regional Policy and Decentralization in the Czech Republic, Regional and Federal Studies, Vol. 16 no. 4., 409-428.

Capello, R., \& Peruccia, G (2013) Do Eastern European Regions Move Towards and Endogenous Growth Pattern? A Diachronic Perspective of Regional Success Factors, WP-1 Task 3. Politecnico di Milano,

European Commission (2010): Investing in Europe's Future - Fifth Report on Economic, Social and Territorial, European Commission, Bruxelles

Blazek, J. (2002): System of Czech Local Governmental Financing as a Framework for Local Development: 12 Years of Trial and Error Approach. Acta Universitatis Carolinae 2002 Geographica No. 2., 154-177. Prague,

Brusis, M. (2003): Regionalisation in the Czech and Slovak Republics: Comparing the Influence of the European Union; (The Regional Challenge in Central and Eastern Europe, Territorial Restructuring and European Integration). Paris, Presses Interuniversitaires Européennes/Peter Lang 2003: 89-105.

Bruszt, L. (2007): Multi-Level Governance - The Eastern Versions Emerging Patterns of Regional Developmental Governance in the New Member States. European University Institute, EUI Working Papers, SPS 2007/13., San Domenico di Fiesole,

Bruszt, L. (2008) Multi-level Governance - the Eastern Versions: Emerging Patterns of Regional Developmental Governance in the New Member States, Regional and Federal Studies, Vol.: 18, No. pp.:607-627 October 2008

Camagni, R. (2009). Territorial capital and regional development. In: (Capello, R. - Nijkamp, P. ed.) Handbook or regional growth and development theories. Northampton, MA. Edward Elgar Publishing. pp. 118-132.

Dabrowski, M. (2007), Implementing Structural Funds in Poland: Institutional Change and Participation of the Civil Society. Political Perpectives, 2007. Vol 1 (2);

European Commission (2014): Country Fact Sheet: Polska. Directorate-General Regional and Urban Policy Analysis Unit, June 2014. Bruxelles,

European Commission (2014): Country Fact Sheet: Slovensko. Directorate-General Regional and Urban Policy Analysis Unit, June 2014. Bruxelles,

European Commission (2014): Country Fact Sheet: Magyarország. Directorate-General Regional and Urban Policy Analysis Unit. 2014. Bruxelles, 
European Commission (2014): Country Fact Sheet: Ceska Republika. Directorate-General Regional and Urban Policy Analysis Unit, June 2014. Bruxelles,

Kulesza, M. (2002): The Polish Experience. (in: Mastering Decentralization and Public Administration Reform in Central and Eastern Europe ed. by Péteri, G.), Open Society Institute, Local Government and Public Service Reform Initiative, Budapest, 189-214 Lóránd, B. (2009), A fejlesztéspolitika sikerességét elősegítő tényezők és a kohéziós országok tapasztalatai Magyarország számára. (Factors Supporting the Success of Development Policy and Experiences of Cohesion Countries for Hungary.) Tér és Társadalom, XXIII/2., 213-224.

Lux, G. (2013): Kritikus tömeg alatt: a fejlesztési együttmüködés lehetőségei a kisebb nagyvárosokban. (Below the critical mass: developmental cooperation in minor cities.) Tér és Társadalom, 27. évf., 4. szám., 52-74.

McMaster, I. (2004): From Regional Deficit to Institutional Overload? - Regional Policy in the Czech Republic. European Policy Research Paper, Number 52, European Policies Research Centre University of Strathclyde, Glasgow,

McMaster I. \& Novotny V. \& Polverari Ch. (2005): Slovakia, Benchmarking Regional Policy in Europe, University of Strathclyde, European Policy Research Centre, Glasgow; http://www.eprc.strath.ac.uk/benchmarking2/documents/Slovakia.pdf

Mezei C. \& Schmidt A. (2013) A lengyel regionális politika és intézményei (Polish regional policy and institutions) Tér és Társadalom / Space and Society 27. évf., 3. szám, 2013 109-124

Michalek, A. \& Podolák, P. (2011), Impact of Key Socio-Economic Disparities on Migration in Slovakia: Economic Diversification vs. Traditional Pattern. European Spatial Research and Policy, 2011. Vol 18. No. 1., 71-87.

Home pages of the ministries:

Poland: http://www.mir.gov.pl/english/Strony/main_mrr_eng.aspx

Czech Republic: http://www.mmr.cz/en/Ministerstvo/Ministerstvo

Slovakia: http://www.telecom.gov.sk/index/index.php

Neuman-S \&, Neuman M. (2010) Domestic Preference Formation in the Czech Republic visá-vis the EU's Foreign and Regional Policy: Polycentrism or Statecentrism? Paper presented at the Fifth Pan-European Conference on EU Politics, 23-26 June 2010. University of Oporto and University of Fernando Pessoa, Porto,

North, D. C. (1994), Economic Performance Through Time; The American Economic Review, Vol 84. No. 3. pp. 359-368.

OECD (2008): Territorial Reviews - Poland. OECD, Paris

OECD (2014): Regions at a Glance. OECD, Paris, http://www.oecd.org/regional/regionalpolicy/regions-at-a-glance.htm

OECD LEED (2012): Delivering Local Development Review to Assess the Efficiency of the Regional Development Agencies Integrated Network of the Slovak Republic. OECD LEED Working Papers 2012/16.

Ostrom, E., \& Ahn, T. K. (2007): The Meaning of Social Capital and its Linkto Collective Action, Workshop in Political Theory and Policy Analysis, Indiana University, Bloomington W/07-19.

Pálné Kovács, I. (2004): A regionális gazdaságfejlesztés igazgatási összefüggései. (The Connection between Regional Economic Development and Public Administration.) in: Pálné Kovács, I. szerk: Versenyképesség és igazgatás. MTA RKK, Pécs, 11-34.

Pálné Kovács I. (2013): Miért hagytuk, hogy így legyen? A területi decentralizációs reformok Magyarországon. (Why we have let this happen? The Regional Decentralization Processes in Hungary.) Politikatudományi Szemle, XXII/4 pp., 7-34. 
Perger, É. (2009): EU kohéziós támogatások felhasználásának intézményrendszere és a forrásfelhasználás hatékonysága, eredményessége, (The institutional system and the effectiveness of using the EU cohesion funds) EcoStat, Budapest.

Perger, É. (2010): Az „Alapok” mellé épült ház. Az EU támogatásokkal kapcsolatos intézményrendszer a magyar közigazgatási struktúrában. (The House Built Next to its Foundation, The EU Funds' Management System in the Hungarian Public Administration Structures.) in: Szigeti E (szerk.): „NYAKTAGI tanulmányok. Kitekintés a közigazgatás müködésének jogi, szervezeti és térszerkezeti kereteire". ECOSTAT, időszaki-közlemények 36. Budapest, 245-338

Perger, É. (2010): Az EU kohéziós politika kormányzati irányításának magyar sajátosságai (The Peculiarities of the EU Cohesions Funds' Hungarian Governance System) Tér és Társadalom 24:(1) pp. 119-136. (2010)

Rechnitzer J. \& Smahó M. (2011): Területi Politika. (Territorial Politics) Akadémiai Kiadó, Budapest

Rodríguez-Pose, A. (2010): Do institutions matter for regional development? Working Papers 2010-02, Instituto Madrileño de Estudios Avanzados (IMDEA) Ciencias Sociales. Madrid,

Šumpíková, M., Pavel, J., \& Klazar, S. (2004, May). EU funds: absorption capacity and effectiveness of their use, with focus on regional level in the Czech Republic. In Conference on Problems Facing the New Member States. Conference proceedings of the 12th NISPAcee Conference. Available at: http://unpan1.un.org/intradoc/groups/public/documents/nispacee/unpan018547.pdf

Tóth Balázs István (2012), Regionális rugalmasság - rugalmas régiók, (Regional Resilience Resilent Regions) Tér és Társadalom 26/2. pp. 3-21.

Vígvári, A. (2008): Szubszidiaritás nélküli decentralizáció néhány adalék az önkormányzati rendszer magyar modelljének korszerüsítéséhez. (Decentralization without Subsidiarity, Some Datums for the Modernization of the Hungarian Local Governmental Finances) Tér és Társadalom, XXII. évf. 2008/1., 141-167.

Weingast, B.R. (1995): The Economic Role of Political Institutions: Market-Preserving Federalism and Economic Development, The Journal of Law Economics and Organization, Vol. 11. Issue: 1. pp.: 1-31.

Wostner, P. (2008): The Micro-efficiency of EU Cohesion Policy European Policy Research Centre, European Policy Research Paper 64. University of Strathclyde, Glasgow. 